\title{
The Influence of Total Quality Management and Export Market Orientation on company export performance of Furniture Industry in Pakistan: A moderating role of Business Network
}

\author{
Muhammad Imran', Abdul Raziq ${ }^{2}$, Mohid Khaliq ${ }^{3}$, Hassan Mujtaba Nawaz Saleem ${ }^{4}$ \\ ${ }^{1}$ Iqra University, Karachi, Pakistan \\ ${ }^{2}$ Iqra University, Karachi, Pakistan \\ ${ }^{3}$ Universiti Utara Malaysia, Sintok, Kedah, Malaysia \\ ${ }^{4}$ The Islamia University of Bahawalpur, Pakistan
}

\begin{abstract}
This study analyzed the moderating role of business network (BN) on the relationship between export market orientation (EMO), total quality management (TQM) and company export performance (CEP). The present study used the Partial Least Squares Structural Equation Modeling (PLS-SEM) technique on sample size 119 furniture manufacturing exporting companies. The results of this study shown the positive significance relationship between EMO, TQM and CEP. Additionally, the study found the moderating role of BN between the relationship of EMO, TQM and CEP. Thus, this revealed that $\mathrm{BN}$ is considered the influential variable to enhancing the effectiveness of EMO and TQM which leads to higher CEP. This study contributes to the literature and to the practice of companies by helping them to understand how the process of EMO, TQM and BN produces better export performance through export market orientation.
\end{abstract}

Keywords: Export market orientation, Total quality management, Business network, company export performance, Furniture industry

\section{Introduction}

Furniture industry of Pakistan consist mostly on small and medium business and spread in Lahore, Gujrat, Peshawar, Chiniot and Karachi (PSDF, 2015). Its contribution to country' economy is around $\$ 160$ million (PSDF, 2015) and providing more than 100,000 employments (Manzoor, 2016). However, the contribution of Pakistan furniture industry in exports have declined from \$18 million in 2007 to $\$ 6$ million during 2016 (LCCI, 2017). This situation is alarming for industry and country economy growth and overall performance of the industry.

Moreover, compared with rivals, Pakistan's furniture industry remains an essentially fragmented, traditional cottage operation with small workshops. Nevertheless, furniture industry of Pakistan should takes the emergent steps to fulfil the $\$ 850$ million export target per year (LCCI, 2017). The higher export decreases the trade deficit, bringing the employment and foreign revenue and economy growth (Ahmad, Afzal, \& Khan, 2017).

However, the main concern of the study is to investigate the antecedents of company export performance (CEP) of furniture industry in Pakistan. Since, furniture industry of Pakistan have potential to achieve the Vision 2025 for economic growth for economic sustainability (Nation, 2016). In the view of globally, many countries have become export-oriented in their approach towards the development of the economy through small industry participation. However, according to past studies total quality management (TQM) is considered the influential factor for higher CEP (Abeykoon \& de Alwis, 2016). Moreover, Lages, Silva, and Styles (2009) stated that owners / mangers should focused on product / service quality which leads to higher CEP. The product or services quality is a critical element in international markets and play the greater role in enhancing the CEP (financial performance). Along with TQM, the export market orientation is considered basic stream for positive CEP (Samson \& Mahmood, 
2015). Besides, Boso, Adeola, Danso, and Assadinia (2017) presented that strong export market orientation to fulfill the customers' needs and introduced the new products / services leads to higher CEP. Thus, deficiency of TQM and EMO in furniture industry might be influenced negatively the company overall performance specially the CEP of furniture industry in Pakistan (Asad, Sharif, Mohd, \& Alekam, 2016; Haroon \& Shariff, 2016). As it is more important elements for higher CEP (M Imran, Hamid, \& Aziz, 2018; Singh, Saufi, \& Hassan, 2017).

Consequently, owners/managers shall emphasis on proper execution of TQM and EMO strategies to enhance the CEP (Bou-Llusar, Escrig-Tena, Roca-Puig, \& Beltrán-Martín, 2009; Mehra, Hoffman, \& Sirias, 2001). Therefore, to address the above discuss issues the present study proposes the TQM and EMO strategies to determine the possible solution of low furniture CEP. Hence the current study primary objective is to investigate the relationship between TQM, EMO and CEP with moderating role of business network (BN).

The current study has major contribution in the literature. The current study proposes moderating role of $\mathrm{BN}$ on the relationship between TQM, EMO and CEP due to two reasons, one to measure the strength of relationship between TQM, EMO and CEP and secondly logical explanation. Since, the relationship between TQM and CEP is not clear yet such some of research found the positive relationship between TQM and CEP (Abeykoon \& de Alwis, 2016; M Imran et al., 2018; Lages et al., 2009; Radzi, Junoh, Hussain, Abd, \& Aziz, 2015) and some of research found insignificant relationship between TQM and CEP (Fatima \& Di Mascio, 2018; Suárez, Calvo-Mora, Roldán, \& Periáñez-Cristóbal, 2017). On the other hand some of researcher found positive significant relationship between EMO and CEP (Alotaibi \& Zhang, 2016; Singh \& Mahmood, 2013; Singh et al., 2017) and some of empirical studies found insignificant relationship between EMO and CEP (Cadogan, Boso, Story, \& Adeola, 2016; Celec, Globocnik, \& Kruse, 2014; Mac \& Evangelista, 2016). Therefore, contradict results are suggested further in-depth investigation of relationship between TQM, EMO and CEP under third variable such as moderating variable. However, the current study taking $\mathrm{BN}$ as moderating variable that $\mathrm{BN}$ has much attention to influencing CEP (Faroque, Morrish, \& Ferdous, 2017) and the past study also suggested that BN might be moderate the relationship between TQM, EMO and CEP (Manuela Presutti, Boari, \& Fratocchi, 2016; Manuela Presutti, Boari, Majocchi, \& Molina-Morales, 2017).

Furthermore, that there are limited studies investigated the relationship between TQM and CEP specifically in context of developing countries such as in context of Pakistan (M Imran, Aziz, \& Hamid, 2017). Besides, Chen, Sousa, and He (2016) reviewed the 124 empirical studies from 2006 to 2014 relating to export performance. They identified that developed countries received more research interest than developing countries and among those studies, no study found in the context of South Asia and as well as in Pakistan context in respect to CEP of furniture industry. Moreover, there are limited studies that investigated the relationship between TQM, EMO and CEP with moderating role of BN in manufacturing firms dominated by industries such as textile, automobile, electrical \& electronics engineering, pharmaceutical, chemical industry and furniture industry. Interestingly, there is not a single comprehensive study available in the context of Pakistan which attempts to identify an effect of TQM and EMO on CEP with moderating role of BN. Therefore, in the view of the above-mentioned gaps and suggestions have motivated to author for further investigation, this study will investigate the influence of total quality management and export market orientation on CEP with moderating role of BN in furniture industry of Pakistan.

The remaining part of the present study structured as follows. After the discussion of study introduction, literature review and hypothesis development will discuss in second portion of the study, third portion of study will discuss the research methodology. Th fourth part of the study will cover the data analysis and findings and last part of the study will debate about the conclusion, implications and recommendations of the study. 


\section{Literature Review and Hypothesis Development}

In this section review the past studies to discuss the construct conceptualization, relationship between exogenous and endogenous variables and propose the study hypothesis. In addition, this portion will cover the study framework.

\section{Company Export performance (CEP)}

Export performance of company is viewed of its ability to enhance the sales, market share, secure the company competition in international market, introduce and offer the innovative and quality products / services to customers (Doktoralina \& Saluy, 2018). Furthermore, export activity is not only important for company higher performance, it is crucial for any country national production growth and increase the revenue. Furthermore, it is also important to be competitive in international markets as well as well in domestic markets. However, owners / managers of the companies should understand the different practices and skills which can enhanced the CEP.

Additionally, CEP can enhance the firm export sales and export profitability, these two dimensions are widely used in literature to measure the export performance (Morgan, Kaleka, \& Katsikeas, 2004). In other study, CEP conceptually defined as the outcome of firm financial performance in the international markets such as export sales, export profitability and export growth (Shoham, 1998). However, according to Shoham (1998) presented that CEP explained in three dimension such as financial, strategic and satisfaction export performance. Nevertheless, these all dimensions of CEP are not well explained in previous studies that which practice, skill can bring the export development or sustainable growth of exports business.

In respect of empirical studies on CEP there are many factors influencing the CEP proved by past studies, although there are many factors influencing the CEP, the current study focused on major or more influential factors which can positively influence the CEP. In the present study is investigating the relationship between TQM, EMO and CEP with moderating effect of BN.

\section{Export market orientation (EMO) and Company Export performance (CEP)}

Export market orientation (EMO) provides the required information for the operations, which can enable to companies for higher CEP. Furthermore, companies due to effective EMO that they can analyse their capabilities to taking competitive advantages and also companies can make changes in their system or operations according to international market business environment. Moreover, EMO allows companies to adopt new strategies towards international market changes and managing and transferring their resources in distinctive way, which can bring sustainable competitive advantages.

In addition, Cadogan, Kuivalainen, and Sundqvist (2009) introduce the EMO concept, he explained that market activities of the firms in international markets termed are export market behavior, which is defined as an export-focused generation, dissemination, and responsiveness to export market intelligence in international markets. More specifically, EMO operationalization to use the Kohli, Jaworski, and Kumar (1993) (MARKOR) scale with export market modification (Cadogan, Diamantopoulos, \& Mortanges, 1999).

In term of relationship between EMO and CEP that past studies stated the mixed results as well. Singh and Mahmood (2013) examined the relationship of EMO and CEP in Malaysia and found the significant positive relationship between two constructs, in other words, EMO found significantly influence to company export profitability, export sales volume, export market share and new export markets. In another study, Samson and Mahmood (2015) investigated the relationship between EMO, and CEP in context of Nigeria. They collected data from 201 Nigerian 'companies and found that EMO positively influenced to CEP. This means firms should have the market capability for superior competitive advantage and business performance. Similarly, Pascucci, Bartoloni, and Gregori (2016) investigated the 
impact of EMO on CEP of 300 Italian' companies. They found that EMO influenced the company export sales.

As contrary, some of authors found the insignificant relationship between EMO and CEP (Cadogan et al., 2016; Celec et al., 2014; Mac \& Evangelista, 2016). Therefore, the contrary finding motivated to present study for further validation of EMO and CEP relationship under the presence of third variable such as BN. Thus, the current study proposed the following hypothesis.

$\mathbf{H}_{1}$ : There is a significant relationship between export market orientation (EMO) and company export performance.

\section{Total quality management (TQM) and Company export performance (CEP)}

Total quality management (TQM) is a strategic activity that focuses to managing the total company to providing the qulaity procudct and services to customers through the mobilisation of employee, management and cohesion of all respources and capabilities of the company (Mehra et al., 2001). Many researchers claimed that TQM is the most advance and most advance technique in the area of quliaty all over the world (Choi \& Eboch, 1998; M. Imran, Zhouquan, Haque, Urbanski, \& Nair, 2018; Lages et al., 2009; Sashkin, 1993). Additionally, Berry (1991) defined that TQM as a management philosophy which purposed to meet and fulfil the customer expectations and consider to reduce the costs. The main purpose of TQM is to provide the quality product and service to customers and alternatively increased the performance of organization with low-cost (Antony, Fergusson, Warwood, \& Hing Yee Tsang, 2004).

Link with previous sentence, TQM as an management approach which characterized by some core concepts that represent the way and procedure to company, which can effecively impliment and will lead to higher performance. Besides, there is no globally accpeted TQM framework (Yusof \& Aspinwall, 2000). Some of approchaces introduced in TQM literature regarding framwork such as consultant base framework, stnadardized framework (ISO 9000;2000), critical factors of TQM and quality award models (Askey \& Dale, 1994; Hendricks \& Singhal, 1996; Petersen, 1999; Saraph, Benson, \& Schroeder, 1989). However, some of reserchers that quality awards fit the definitation of TQM take into account its major elements, and they considered the valid framework for TQM (Bou-Llusar et al., 2009). Furthermore, quality award such as European Foundation for Quality Management (EFQM) has not valaidated empirically, this assumption motivates to current study that operationlize the TQM on based of EFQM. The EFQM created in 1991 as framework to recognise the company excellence (Gómez, Martinez Costa, \& Martínez Lorente, 2017).

Morover, the relationship between TQM and CEP investigated the relationship between TQM and firm performance and found the positive relationship between TQM and firm performance (Lee \& Lee, 2014). According to Munizu (2013) stated that TQM has a positive and significant effect of competitive advantage which leads to high CEP. In another study, Abeykoon and de Alwis (2016) investigated the TQM activities such as employee management, leadership, training, supplier management, customer focus, process management, information and analysis and continuous improvement on the CEP of appeal exporter firms of Sri Lanka. In this study author used the 65 apparel exporters and analyzed the data through correlation and regression analysis and found the positive relationship between TQM and CEP. Therefore, most of the studies have been done in domestic market only very limited research studies investigated the relationship between TQM and CEP, especially in furniture industry of Pakistan. Hence, the present study believe that TQM would be a key driving force for CEP. Thus, the following hypothesis is proposed;

$\mathbf{H}_{2}$ : There is a significant relationship between total quality management (TQM) and company export performance. 


\section{Moderating role of Business Network between Total quality management, Export Market Orientation and CEP}

Business network (BN) refer to inter firm networks that can build the relationship between companies and these relationships are regularly formalized (Dubini \& Aldrich, 1991). Furthermore, these relationships should be formal between owners / managers and employees of company. The current study conceptualized the BN in line with company export performance literature. However, this study focusses on furniture export companies in developing countries, and also focus on BN with foreign partners which play a vital role in achieving the high CEP.

More specifically, published studies have underlined the importance of BN for enhancing the CEP benefits of EMO and TQM (De Ruyter \& Semeijn, 2002; M Presutti \& Odorici, 2018; Terziovski, 2003). Moreover, BN defined that developed the relationship with overseas customers, suppliers and competitors in the industry (Faroque et al., 2017). These relationships arevery importance EMO in respect of information acquisition that enable the export markets activities to be implement rapidly to reduce the cost of time and other resources of the company (Bucktowar, Kocak, \& Padachi, 2015). Additionally, BN can be the important predictor of CEP because BN activity increases the exchange of ideas, knowledge, resources among partners, and also can improve coordination among partners, customers, suppliers to reduce the transactions costs (Thornton, Henneberg, \& Naudé, 2013). In other words, company with strong $\mathrm{BN}$ enhance the effectiveness of export market intelligence generation and responsiveness component of EMO (M Presutti \& Odorici, 2018).

In respect of TQM implementation, the companies with increasing levels of BN enhance usefulness of TQM which leads to enhance the CEP (De Ruyter \& Semeijn, 2002; Wu \& Chiu, 2016). Furthermore, companies who has higher share of export sales, they have interest to build and make strong the BN with less experience exporter that companies have chanced continuously improve the product and service quality and process efficiency (Schmitz \& Knorringa, 2000).

Therefore, the present study proposed the following hypothesis:

$\mathbf{H}_{3}$ : Business network moderate the relationship between EMO and CEP

$\mathrm{H}_{4}$ : Business network $(\mathrm{BN})$ moderate the relationship between TQM and CEP 


\section{Framework}

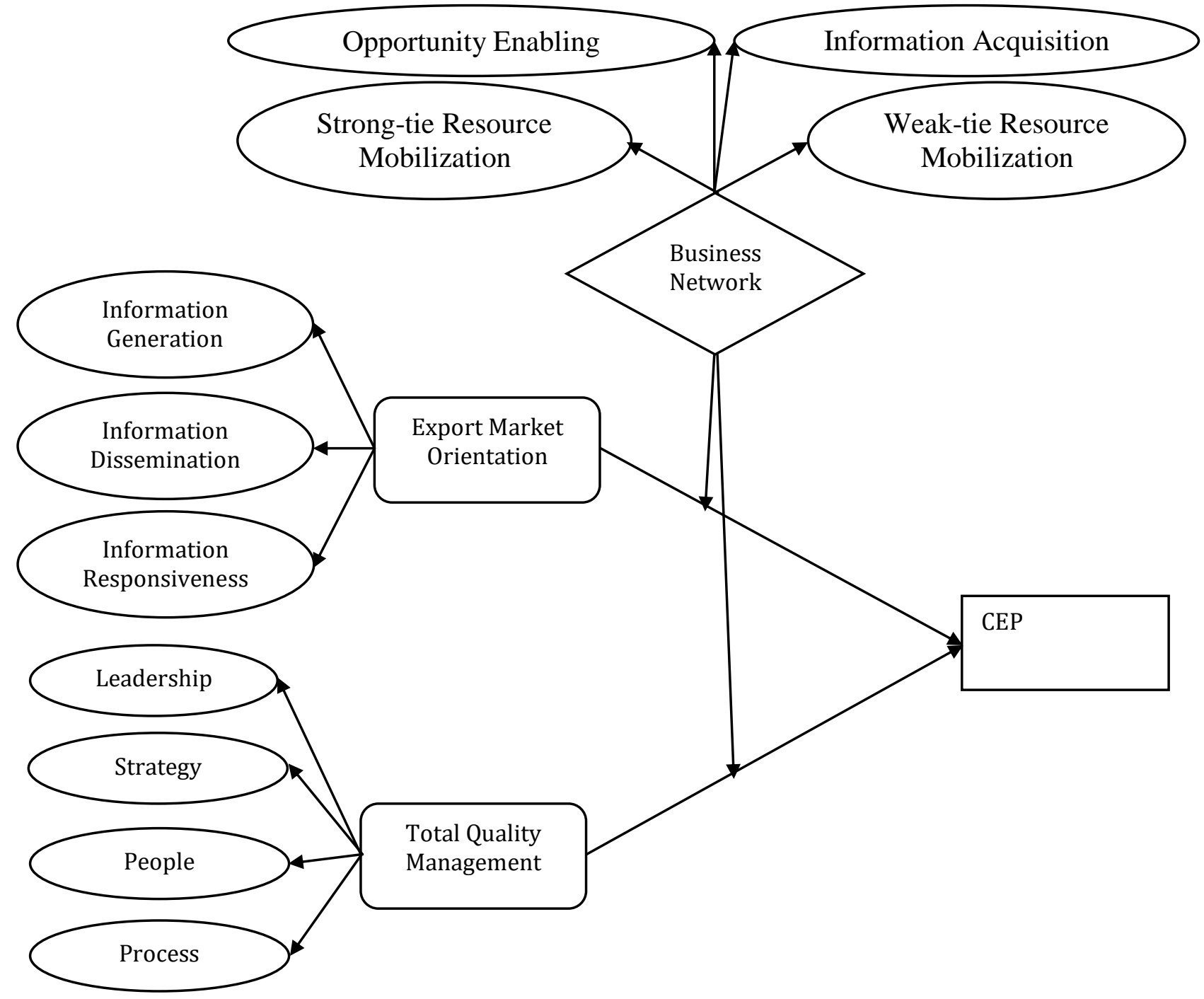

Figure1 Study framework

The current study framework consists of two exogenous variables such as EMO with three dimensions namely, information generation, information dissemination, information responsiveness and second one is TQM with four dimensions namely, leadership, strategy, people and process. The study has one moderating variable BN with four dimensions namely, information acquisition, opportunity enabling, strong-tie resource mobilization, weak-tie resource mobilization and one endogenous variable company export performance.

\section{Methods}

\section{Population, sample size, and respondent}

The present research work was taken the furniture manufacturing exporting companies of Pakistan as population of the study. The three hundred twenty-one (321) furniture manufacturing exporting companies were qualified for the current study sample; this list has been taken from Pakistan exporter 
directory.

The study used the $G^{*}$ Power 3.1.9.2 software to determine the minimum sample size of the study (Faul, Erdfelder, Lang, \& Buchner, 2007). However, the study found the 89 total sample size of the study, the result can be seen in the Figure 2. Additionally, to minimize sampling error and maximum response rate, increased the total sample size (Salkind, 2012). However, the study distributed the 245 questionnaires to adopt the simple random sampling technique. The random selection made through Microsoft excel 2016 (RAND) function (Saunders \& Lewis, 2015).

A total of 245 questionnaires distributed to furniture industry firms, only 119 firms participated in the survey with a response rate of $48 \%$. This response is acceptable and better than previous furniture industry response such as 31\% response rate is recorded in the study of (Sidin, 2017).

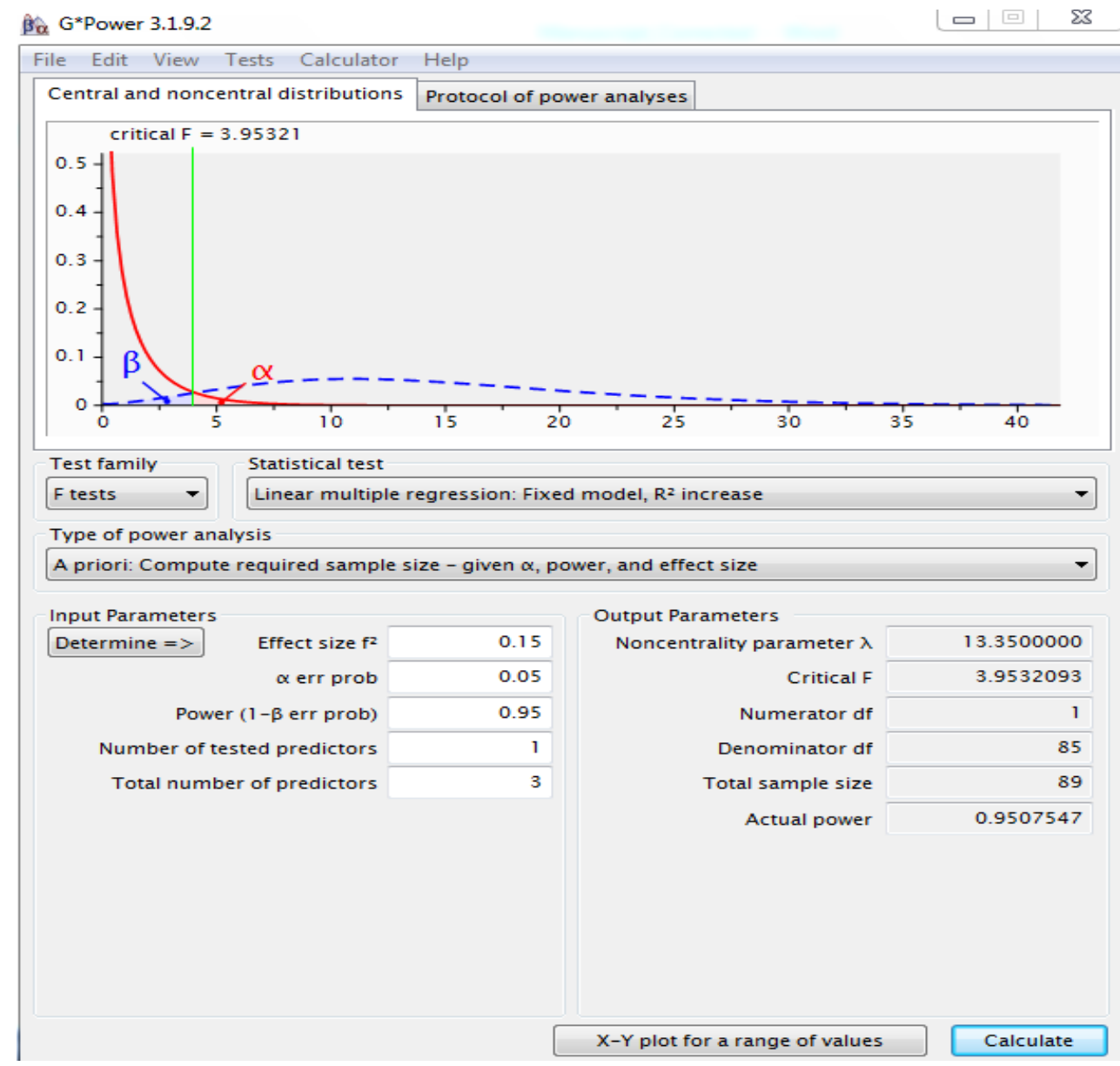

Figure $2 \mathrm{G}^{*}$ Power sample calculation

\section{Measures of variables}

Measures of the variable adapted from past studies. The study consists of four variables including total EMO, TQM as an independent variable, $\mathrm{BN}$ as a moderating variable, and CEP as the dependent variable. The total quality management in this study contains four dimensions, where the leadership, strategy, people and process contained 6, 6, 6 and 7 respectively adapted from (Shafiq, Lasrado, \& Hafeez, 2017), second independent variable EMO contained three dimensions namely information generation, information dissemination, information responsiveness with 5, 5 and 3 items respectively, this scale adapted from the study of Cadogan, Paul, Salminen, Puumalainen, and Sundqvist (2001). The BN scale was adapted from the 
study of Thornton, Henneberg, and Naudé (2015) with four dimensions namely information acquisition, opportunity enabling, strong-tie resource mobilization, weak-tie resource mobilization with 4, 4, 4 and 4 items each. Finally, the dependent variable scale adapted from the study of Shoham (1998) as unidimensional construct.

\section{Data Analysis and Results}

SmartPLS-3 was employed for the analysis of partial least square structural equation modeling (LSSEM). program is used for SEM analysis of data processing to test the feasibility of measurement models and structural models. The present study used the second-order reflective-reflective hierarchical model, type I (Becker, Klein, \& Wetzels, 2012). However, EMO, TQM AND BN treated as second order construct and CEP treated as first order construct in this present study. Additionally, the decision to measure a construct reflectively or formatively is not clear yet (Hair Jr, Hult, Ringle, \& Sarstedt, 2016). Besides, Hair Jr, Sarstedt, Ringle, and Gudergan (2017) suggested that the best combination in second order is a reflective-reflective model. Hence, the present study adopts the reflective-reflective model in our current study.

\section{Measurement Model}

Measurement model was evaluated the constructs Internal Consistency and Convergent Validity. Cronbach alpha, composite reliability criteria are used to measure the model constructs internal consistency (Henseler, Ringle, \& Sinkovics, 2009). Hair, Hult, Ringle, and Sarstedt (2014) stated that the value of 0.70 is acceptable. However, the Cronbach alpha values found between 0.904 to 0.716 . The Composite reliability (CR) values should be greater than 0.70 as well (Nunnally \& Bernstein, 1978). The values of CR found between the range of 0.923 to 0.840 . In other words, according to Bagozzi and Yi (1988) presented that 0.70 value of composite reliability indicates that internal consistency reliability is extremely satisfying and favorable.

Hair Jr et al. (2016) mentioned that the Average Variance Extracted (AVE) value greater should greater than 0.50 , then the convergent validity is considered acceptable. This study found that AVE values of the reflective constructs were ranged from 0.634 to 0.716 . Subsequently, it established satisfactory convergent validity for reflective $1^{\text {st }}$ order constructs measurement model. Hence the measurement model of the study validated successfully. The results can be seen in table 4.1 and the figure 4.1 can see the items loading, in respect of loading should be greater than 0.50 (Hair et al., 2014).

Table 1 Finding of the measurement model (First Order, Reflective)

\begin{tabular}{llll}
\hline \multicolumn{1}{c}{ Constructs } & $\begin{array}{c}\text { Cronbach's } \\
\text { Alpha }\end{array}$ & $\begin{array}{c}\text { Composite } \\
\text { Reliability }\end{array}$ & $\begin{array}{c}\text { Average Variance } \\
\text { Extracted (AVE) }\end{array}$ \\
\hline Export market information dissemination & 0.904 & 0.923 & 0.750 \\
\hline Export market information generation & 0.811 & 0.874 & 0.634 \\
\hline Export market responsiveness & 0.716 & 0.840 & 0.638 \\
\hline Information Acquisition & 0.775 & 0.87 & 0.693 \\
\hline Leadership & 0.777 & 0.869 & 0.689 \\
\hline Opportunity Enabling & 0.871 & 0.908 & 0.712 \\
\hline People & 0.898 & 0.921 & 0.66 \\
\hline Process & 0.893 & 0.914 & 0.603 \\
\hline CEP & 0.930 & 0.942 & 0.670 \\
\hline Strategy & 0.823 & 0.880 & 0.647 \\
\hline Strong ties resources mobilization & 0.749 & 0.856 & 0.665 \\
\hline Weak ties resources mobilization & 0.785 & 0.861 & 0.608 \\
\hline
\end{tabular}




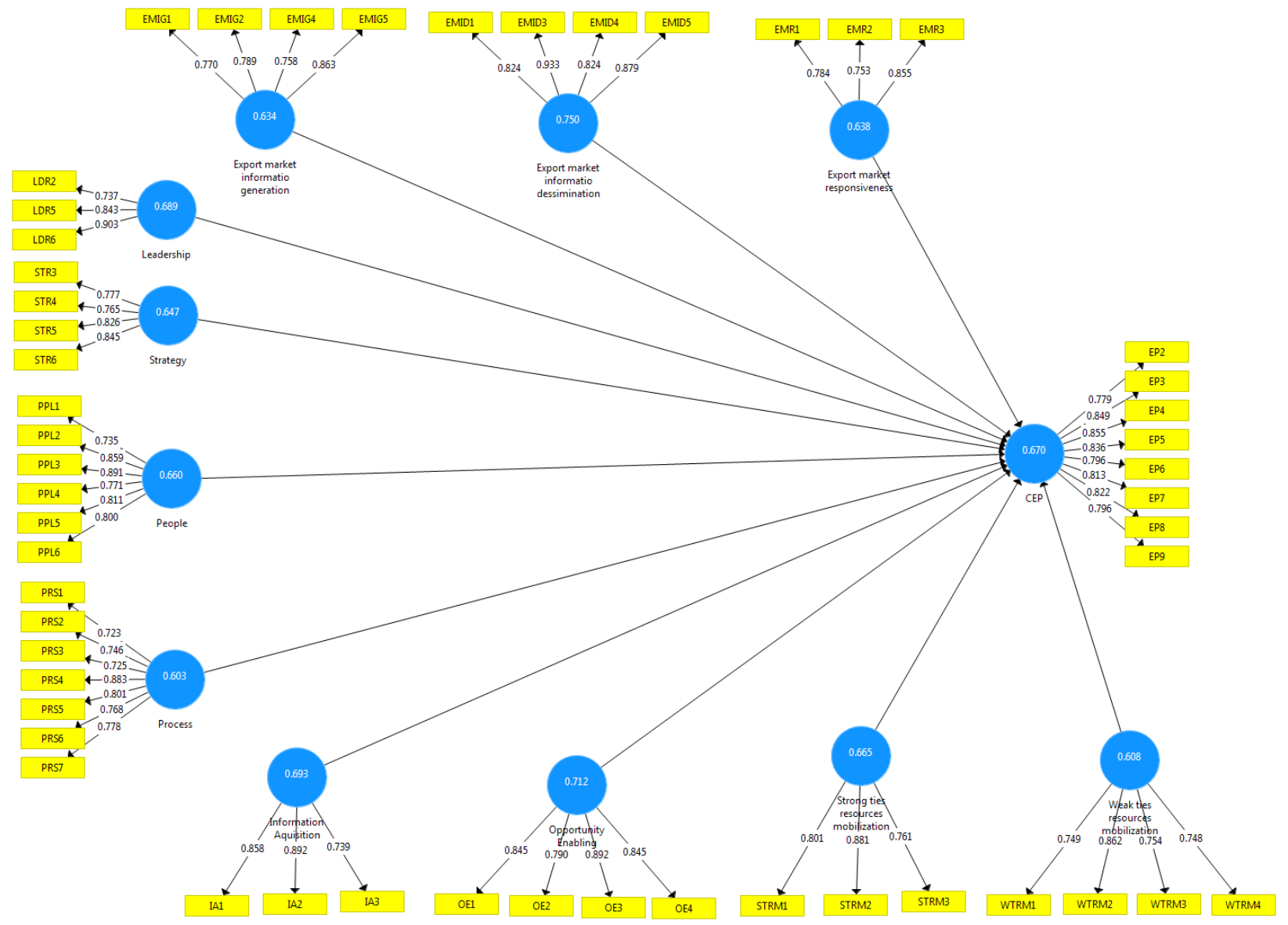

Figure 3 Measurement Model (Items loading and AVE) 
Moreover, discriminant validity was analysed to determine the model external consistency, based on the correlation among the latent variables, however, the value of the variables compared with the square root of AVEs. Finally, as explained in table 4.2 all the correlations among the variables are lower than square root-averages (AVEs) of which are highlighted (Bolded) in crosswise.

In addition, the HTMT index offers the latest criteria, this criteria is useful measures the external consistency of the constructs (Henseler, Ringle, \& Sarstedt, 2015). Furthermore, this criterion is better to overcome the error in Fornell and larcker criteria and cross loading test. The HTMT index is the average of the heterotrait-heteromethod correlations relative to the average monotrait-heteromethod correlations. All values of HTMT index should be less than 0.90 , thereby confirming discriminant validity (Henseler et al., 2015). Table 4.3 representing HTMT result.

Table 2 Fornell-Larcker Criterion

\begin{tabular}{|c|c|c|c|c|c|c|c|c|c|c|c|c|}
\hline Constructs & $\begin{array}{l}\text { Export } \\
\text { market } \\
\text { informat } \\
\text { ion } \\
\text { dissemin } \\
\text { ation }\end{array}$ & $\begin{array}{l}\text { Export } \\
\text { market } \\
\text { inform } \\
\text { ation } \\
\text { generat } \\
\text { ion }\end{array}$ & $\begin{array}{l}\text { Export } \\
\text { market } \\
\text { responsiv } \\
\text { eness }\end{array}$ & $\begin{array}{l}\text { Inform } \\
\text { ation } \\
\text { Acquisi } \\
\text { tion }\end{array}$ & $\begin{array}{l}\text { Leader } \\
\text { ship }\end{array}$ & $\begin{array}{l}\text { Opport } \\
\text { unity } \\
\text { Enablin } \\
\mathrm{g}\end{array}$ & $\begin{array}{l}\text { Peop } \\
\text { le }\end{array}$ & $\begin{array}{l}\text { Proc } \\
\text { ess }\end{array}$ & CEP & $\begin{array}{l}\text { Strat } \\
\text { egy }\end{array}$ & $\begin{array}{l}\text { Strong } \\
\text { ties } \\
\text { resourc } \\
\text { es } \\
\text { mobiliz } \\
\text { ation }\end{array}$ & $\begin{array}{l}\text { Weak } \\
\text { ties } \\
\text { resourc } \\
\text { es } \\
\text { mobiliz } \\
\text { ation }\end{array}$ \\
\hline $\begin{array}{l}\text { Export market information } \\
\text { dissemination }\end{array}$ & 0.866 & & & & & & & & & & & \\
\hline $\begin{array}{l}\text { Export market information } \\
\text { generation }\end{array}$ & -0.024 & 0.796 & & & & & & & & & & \\
\hline $\begin{array}{ll}\text { Export } & \text { market } \\
\text { responsiveness } & \\
\end{array}$ & 0.105 & 0.406 & 0.799 & & & & & & & & & \\
\hline Information Acquisition & 0.103 & 0.217 & 0.167 & 0.832 & & & & & & & & \\
\hline Leadership & -0.073 & 0.453 & 0.431 & 0.226 & 0.83 & & & & & & & \\
\hline Opportunity Enabling & 0.002 & 0.414 & 0.348 & 0.481 & 0.269 & 0.844 & & & & & & \\
\hline People & -0.053 & 0.354 & 0.326 & 0.251 & 0.621 & 0.19 & 0.813 & & & & & \\
\hline Process & -0.285 & 0.425 & 0.117 & 0.091 & 0.479 & 0.306 & 0.556 & 0.776 & & & & \\
\hline CEP & 0.081 & 0.283 & 0.5 & 0.234 & 0.565 & 0.291 & 0.527 & 0.332 & 0.819 & & & \\
\hline Strategy & -0.109 & 0.341 & 0.317 & 0.195 & 0.58 & 0.253 & 0.718 & 0.552 & 0.477 & 0.804 & & \\
\hline $\begin{array}{l}\text { Strong ties resources } \\
\text { mobilization }\end{array}$ & 0.046 & 0.489 & 0.245 & 0.244 & 0.256 & 0.568 & 0.121 & 0.321 & 0.292 & 0.274 & 0.816 & \\
\hline $\begin{array}{l}\text { Weak ties resources } \\
\text { mobilization }\end{array}$ & 0.132 & 0.503 & 0.431 & 0.401 & 0.441 & 0.623 & 0.42 & 0.345 & 0.415 & 0.348 & 0.493 & 0.78 \\
\hline
\end{tabular}


Table 3 Heterotrait-Monotrait Ratio (HTMT)

\begin{tabular}{|c|c|c|c|c|c|c|c|c|c|c|c|c|}
\hline Constructs & $\begin{array}{l}\text { Export } \\
\text { market } \\
\text { informat } \\
\text { ion } \\
\text { dissemin } \\
\text { ation }\end{array}$ & $\begin{array}{l}\text { Export } \\
\text { market } \\
\text { inform } \\
\text { ation } \\
\text { generat } \\
\text { ion }\end{array}$ & $\begin{array}{l}\text { Export } \\
\text { market } \\
\text { responsi } \\
\text { veness }\end{array}$ & $\begin{array}{l}\text { Inform } \\
\text { ation } \\
\text { Acquisi } \\
\text { tion }\end{array}$ & $\begin{array}{l}\text { Leader } \\
\text { ship }\end{array}$ & $\begin{array}{l}\text { Opport } \\
\text { unity } \\
\text { Enablin } \\
g\end{array}$ & $\begin{array}{l}\text { Peop } \\
\text { le }\end{array}$ & $\begin{array}{l}\text { Proc } \\
\text { ess }\end{array}$ & CEP & $\begin{array}{l}\text { Strat } \\
\text { egy }\end{array}$ & $\begin{array}{l}\text { Strong } \\
\text { ties } \\
\text { resource } \\
\text { s } \\
\text { mobiliz } \\
\text { ation }\end{array}$ & $\begin{array}{l}\text { Weak } \\
\text { ties } \\
\text { resource } \\
\text { s } \\
\text { mobiliz } \\
\text { ation }\end{array}$ \\
\hline \multicolumn{13}{|l|}{$\begin{array}{l}\text { Export market information } \\
\text { dissemination }\end{array}$} \\
\hline $\begin{array}{l}\text { Export market information } \\
\text { generation }\end{array}$ & 0.139 & & & & & & & & & & & \\
\hline Export market responsiveness & 0.143 & 0.54 & & & & & & & & & & \\
\hline Information Acquisition & 0.162 & 0.274 & 0.266 & & & & & & & & & \\
\hline Leadership & 0.127 & 0.593 & 0.57 & 0.287 & & & & & & & & \\
\hline Opportunity Enabling & 0.115 & 0.487 & 0.424 & 0.607 & 0.325 & & & & & & & \\
\hline People & 0.112 & 0.426 & 0.392 & 0.309 & 0.715 & 0.23 & & & & & & \\
\hline Process & 0.328 & 0.508 & 0.198 & 0.148 & 0.561 & 0.356 & 0.642 & & & & & \\
\hline CEP & 0.124 & 0.296 & 0.594 & 0.27 & 0.639 & 0.283 & 0.545 & 0.326 & & & & \\
\hline Strategy & 0.152 & 0.434 & 0.402 & 0.277 & 0.7 & 0.306 & 0.824 & 0.64 & 0.502 & & & \\
\hline $\begin{array}{l}\text { Strong ties resources } \\
\text { mobilization }\end{array}$ & 0.142 & 0.624 & 0.375 & 0.344 & 0.321 & 0.658 & 0.157 & 0.377 & 0.348 & 0.34 & & \\
\hline $\begin{array}{l}\text { Weak ties resources } \\
\text { mobilization }\end{array}$ & 0.181 & 0.629 & 0.576 & 0.529 & 0.57 & 0.718 & 0.484 & 0.382 & 0.458 & 0.428 & 0.609 & \\
\hline
\end{tabular}

\section{Structural Model Assessment}

The structural model used to make the decision regarding hypothesis acceptance and rejection. In structural model used the path coefficient, $R^{2}$ and $f^{2}$ criteria to validate the structural model in this present study.

In respect of path coefficient, Henseler et al. (2009) stated that, the path coefficients are like regression analysis and standardized beta coefficient. The rule of thumb revealed by Hair et al. (2014), which explains that Bootstrapping method was performed (with 5000 sampling iterations for 119 cases/observations) to determine the beta-values of the coefficient of the regression and t-values which must be greater than 1.96 to considered resulted value significant. The main objective of the present study is evaluated the relationship between the constructs.

The result of path coefficient shown the positive and significant relationship between EMO, TQM and CEP. The results can be seen in table 4 . 
Table 4 direct relationship between construct

\begin{tabular}{lcccrr}
\hline Hypothesis & Beta & $\begin{array}{l}\text { Standard } \\
\text { Deviation }\end{array}$ & T Values & P Values & Decision \\
\hline H1: Export market orientation $\rightarrow$ company export performance & 0.246 & 0.094 & 2.605 & 0.009 & Supported \\
H2: Total quality management $->$ company export performance & 0.445 & 0.117 & 3.795 & 0.000 & Supported \\
\hline
\end{tabular}

Furthermore, the moderating effect of BN between EMO, TQM and CEP found positive and significant. The results can be seen in table 5 .

Table 5 Moderation relationship

\begin{tabular}{|c|c|c|c|c|c|}
\hline Hypothesis & Beta & SD & T Values & P Values & Decision \\
\hline Moderating Effect 1 -> company export performance & 0.223 & 0.106 & 2.109 & 0.035 & \\
\hline Moderating Effect 2 -> company export performance & 0.156 & 0.083 & 1.874 & 0.061 & \\
\hline
\end{tabular}




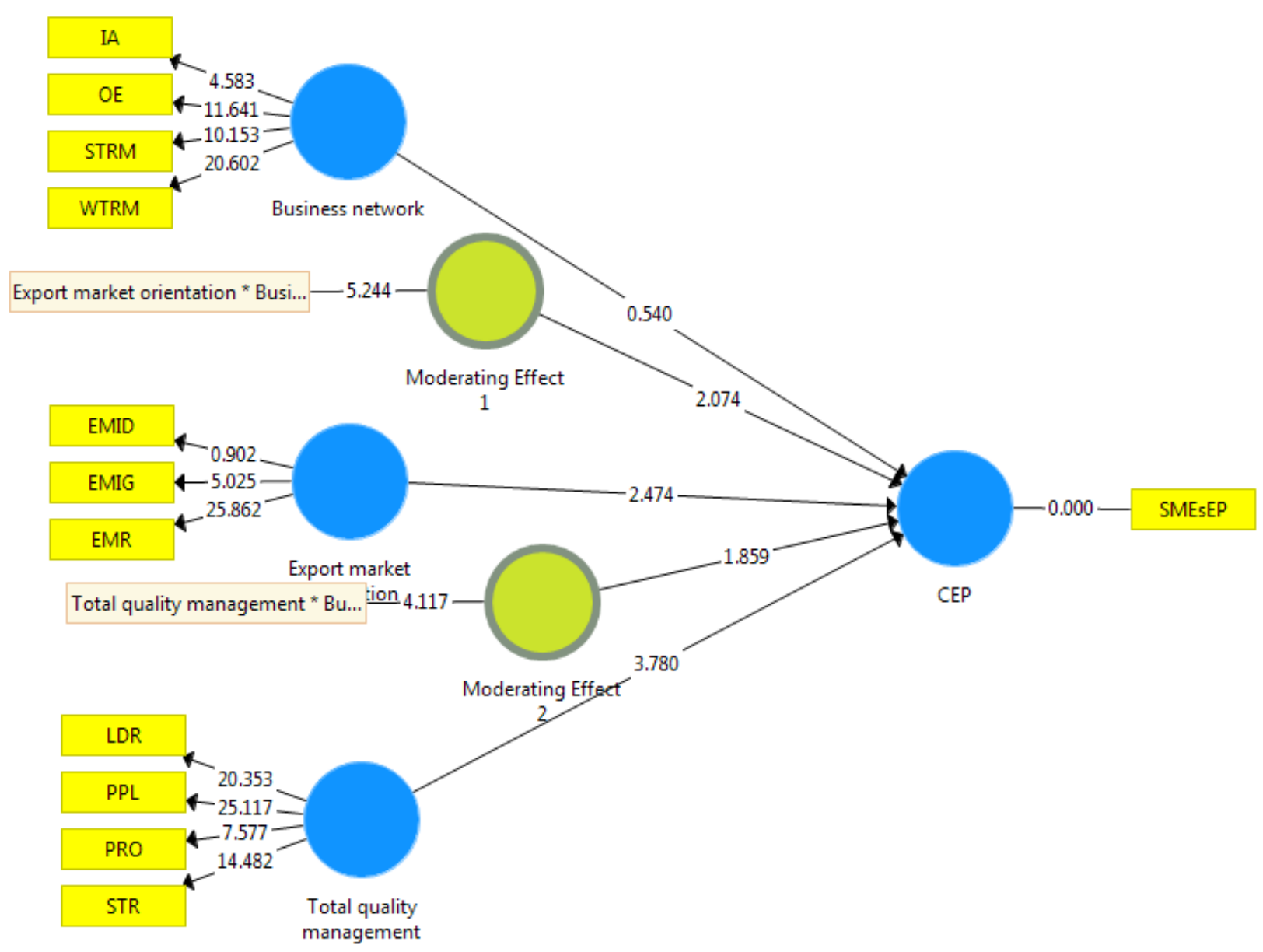

Figure 4 Structural Model

$R^{2}$ mean the contribution of all endogenous variable in endogenous variable. However, in respect of $R^{2}$ that the values of $R^{2} 0.25$ considered weak, 0.50 considered moderate and 0.75 considered excellent. The effect size $\left(f^{2}\right)$ mean the individual contribution of iv into $d v$, however, in term of $\mathrm{f} 2$ values that considered small (0.02), medium (0.15) and large (0.35) respectively. The result can be seen in table 6

Table 6 The result of $R^{2}$ and $f^{2}$

\begin{tabular}{lcccc}
\hline Constructs & \multicolumn{2}{c}{$f^{2}$} & \multicolumn{2}{c}{$\boldsymbol{R}^{2}$} \\
\hline & BN & EMO & CEP & CEP \\
Business network & & 0.004 & 0.451 \\
Export market orientation & & 0.072 & \\
Total quality management & & & 0.247 & \\
\hline
\end{tabular}

\section{Conclusion}

The present study results show the positive and significant relationship between EMO, TQM and CEP, hence the hypothesis H1, H2 accepted. This current study result consistent with past studies as well (M. Imran et al., 2018; Singh et al., 2017). Furthermore, the moderating role of BN between EMO, TQM and $\mathrm{CEP}$ found significant. The figure 7 and figure 8 represented the $\mathrm{BN}$ moderating role that $\mathrm{BN}$ playing the role to enhancing the or strengthen the relationship between EMO and CEP, same goes with figure 2 
show the moderating role of $\mathrm{BN}$ that enhancing or strength the relationship between TQM and CEP. In other words, BN playing influential role in effectiveness of EMO and proper implementation of TQM to leads to higher CEP.

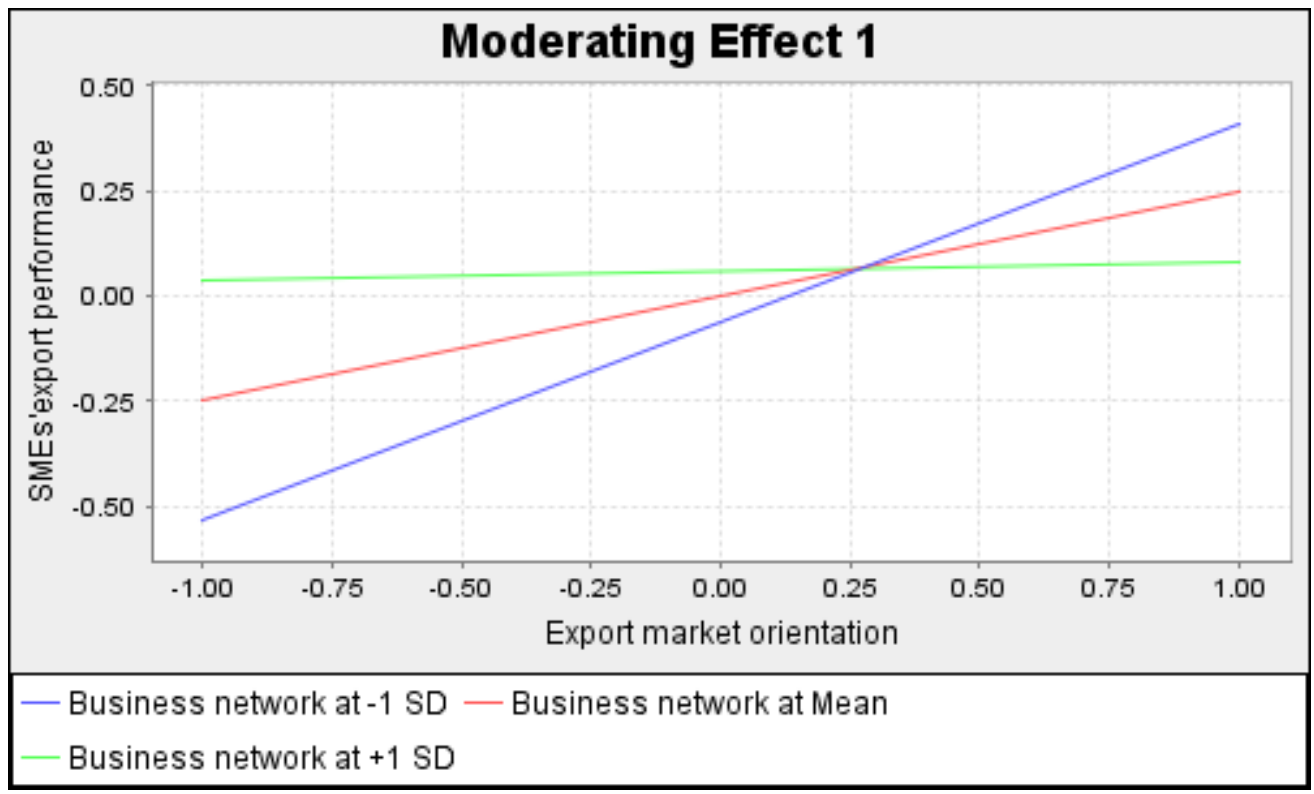

Figure 7 Moderating role of $\mathrm{BN}$ on the relationship between EMO and CEP

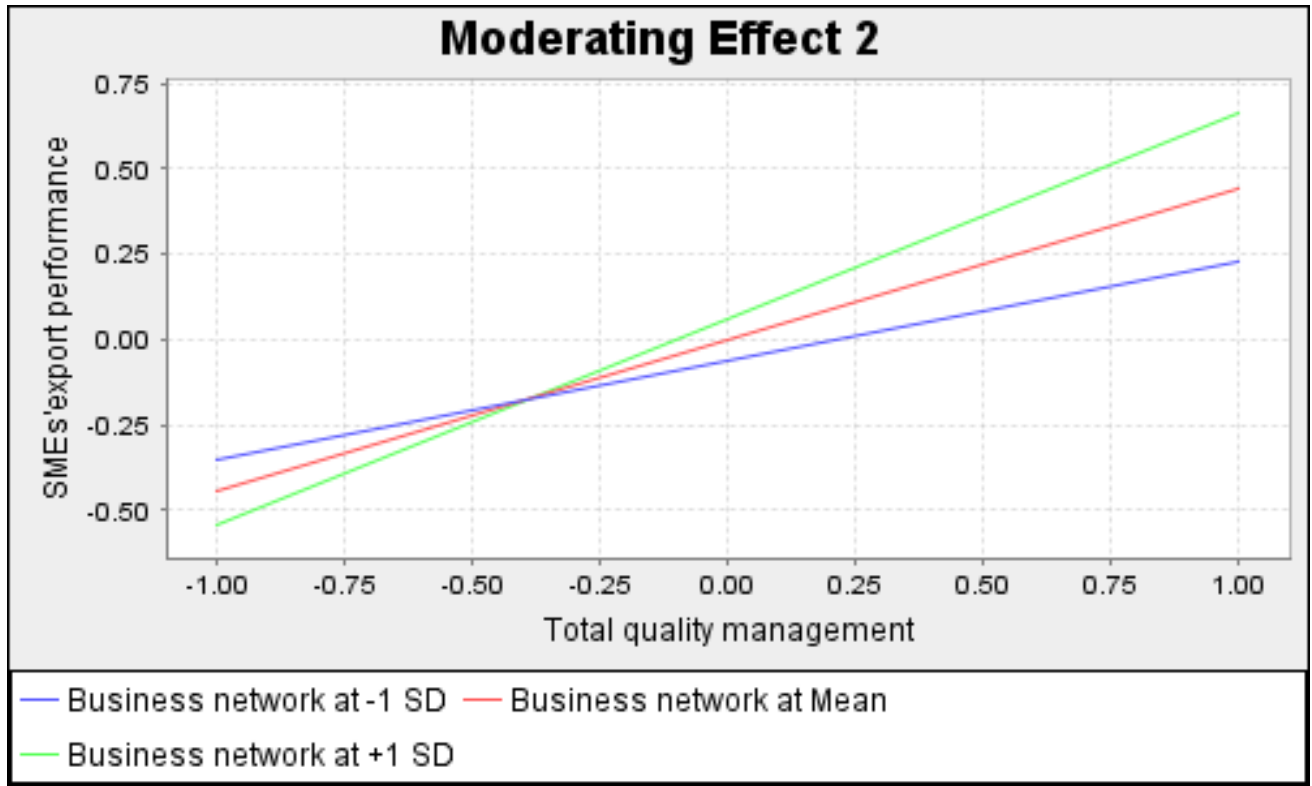

Figure 8 Moderating role of $\mathrm{BN}$ on the relationship between TQM and CEP

The current study suggests to owners / managers to implement the EMO, TQM strategies under the presence of BN ties with partners, customer, suppliers which will increase the company export performance However, these variables are very important in context of Pakistan. The government take serious notes in respect the implementation of EMO, TQM and building string networking with 
neighboring countries, such as India, Afghanistan, Iran and China. These strategies will have benefited to industry which leads to higher export performance, which overcome the country debt as well.

\section{References}

Abeykoon, M., \& de Alwis, A. (2016). The Impact of Total Quality Management Practices on Export Performance of Apparel Exporters of Sri Lanka. Kelaniya Journal of Human Resource Management, 10(1).

Ahmad, D., Afzal, M., \& Khan, U. G. (2017). Impact of Exports on Economic Growth Empirical Evidence of Pakistan. International Journal of Applied, 5(2).

Alotaibi, M. B. G., \& Zhang, Y. (2016). The relationship between export market orientation and export performance: an empirical study. Applied Economics, 1-6.

Antony, J., Fergusson, C., Warwood, S., \& Hing Yee Tsang, J. (2004). Comparing total quality management success factors in UK manufacturing and service industries: some key findings from a survey. Journal of Advances in Management Research, 1(2), 32-45.

Asad, M., Sharif, M., Mohd, N., \& Alekam, J. M. E. (2016). Moderating effect of entrepreneurial networking on the relationship between entrepreneurial orientation and performance of micro and small enterprises. Science International, 28(2).

Askey, J., \& Dale, B. (1994). Internal quality management auditing: an examination. Managerial Auditing Journal, 9(4), 3-10.

Bagozzi, R. P., \& Yi, Y. (1988). On the evaluation of structural equation models. Journal of the academy of marketing science, 16(1), 74-94.

Becker, J.-M., Klein, K., \& Wetzels, M. (2012). Hierarchical latent variable models in PLS-SEM: guidelines for using reflective-formative type models. Long Range Planning, 45(5), 359-394.

Berry, T. H. (1991). Managing the total quality transformation: McGraw-Hill.

Boso, N., Adeola, O., Danso, A., \& Assadinia, S. (2017). The effect of export marketing capabilities on export performance: Moderating role of dysfunctional competition. Industrial Marketing Management.

Bou-Llusar, J. C., Escrig-Tena, A. B., Roca-Puig, V., \& Beltrán-Martín, I. (2009). An empirical assessment of the EFQM Excellence Model: Evaluation as a TQM framework relative to the MBNQA Model. Journal of Operations Management, 27(1), 1-22.

Bucktowar, R., Kocak, A., \& Padachi, K. (2015). Entrepreneurial Orientation, Market Orientation And Networking: Impact On Innovation And Firm Performance. Journal of Developmental Entrepreneurship, 20(04), 1550024.

Cadogan, J. W., Boso, N., Story, V. M., \& Adeola, O. (2016). Export strategic orientation-performance relationship: Examination of its enabling and disenabling boundary conditions. Journal of Business Research.

Cadogan, J. W., Diamantopoulos, A., \& Mortanges, D. (1999). A measure of export market orientation: Scale development and cross-cultural validation. Journal of International Business Studies, 30(4), 689707.

Cadogan, J. W., Kuivalainen, O., \& Sundqvist, S. (2009). Export market-oriented behavior and export performance: quadratic and moderating effects under differing degrees of market dynamism and internationalization. Journal of International Marketing, 17(4), 71-89.

Cadogan, J. W., Paul, N. J., Salminen, R. T., Puumalainen, K., \& Sundqvist, S. (2001). Key antecedents to "export" market-oriented behaviors: a cross-national empirical examination. International Journal of Research in Marketing, 18(3), 261-282.

Celec, R., Globocnik, D., \& Kruse, P. (2014). Resources, capabilities, export performance and the moderating role of entrepreneurial orientation in the context of SMEs. European Journal of 
International Management, 8(4), 440-464.

Chen, Sousa, C., \& He, X. (2016). The determinants of export performance: a review of the literature 20062014. International Marketing Review, 33(5), 626-670.

Choi, T. Y., \& Eboch, K. (1998). The TQM paradox: relations among TQM practices, plant performance, and customer satisfaction. Journal of Operations Management, 17(1), 59-75.

De Ruyter, K., \& Semeijn, J. (2002). Forging buyer-seller relationships for total quality management in international business: the case of the European cement industry. Total Quality Management, 13(3), 403-417.

Doktoralina, E. R. C. M., \& Saluy, A. B. (2018). Development Model of Marketing Capabilities and Export Performance of SMEs: A Proposed Study. Development, 10(22).

Dubini, P., \& Aldrich, H. (1991). Personal and extended networks are central to the entrepreneurial process. Journal of Business Venturing, 6(5), 305-313.

Faroque, A. R., Morrish, S. C., \& Ferdous, A. S. (2017). Networking, business process innovativeness and export performance: the case of South Asian low-tech industry. Journal of Business \& Industrial Marketing, 32(6), 864-875.

Fatima, J. K., \& Di Mascio, R. (2018). Reversing the dependency-trust relationship in B2C services. Journal of Retailing and Consumer Services, 41, 1-10.

Faul, F., Erdfelder, E., Lang, A.-G., \& Buchner, A. (2007). G* Power 3: A flexible statistical power analysis program for the social, behavioral, and biomedical sciences. Behavior research methods, 39(2), 175191.

Gómez, J. G., Martinez Costa, M., \& Martínez Lorente, Á. R. (2017). EFQM Excellence Model and TQM: an empirical comparison. Total Quality Management \& Business Excellence, 28(1-2), 88-103.

Hair, J. F., Hult, G. T. M., Ringle, C. M., \& Sarstedt, M. (2014). A Primer on Partial Least Squares Structural Equation Modeling (PLS-SEM). Los Angeles, CA: SAGE.

Hair Jr, J. F., Hult, G. T. M., Ringle, C., \& Sarstedt, M. (2016). A primer on partial least squares structural equation modeling (PLS-SEM) (2nd ed.). Thousand Oaks, CA: SAGE.

Hair Jr, J. F., Sarstedt, M., Ringle, C. M., \& Gudergan, S. P. (2017). Advanced issues in partial least squares structural equation modeling. Los Angeles, CA: SAGE Publications.

Haroon, U., \& Shariff, M. N. M. (2016). The interplay of innovation, tqm practices and smes performance in Pakistan: Moderating effects of knowledge inertia and external environment. South East Asia Journal of Contemporary Business, Economics and Law, 9(2).

Hendricks, K. B., \& Singhal, V. R. (1996). Quality awards and the market value of the firm: An empirical investigation. Management science, 42(3), 415-436.

Henseler, J., Ringle, C. M., \& Sarstedt, M. (2015). A new criterion for assessing discriminant validity in variance-based structural equation modeling. Journal of the Academy of Marketing Science, 43(1), 115-135.

Henseler, J., Ringle, C. M., \& Sinkovics, R. R. (2009). The use of partial least squares path modeling in international marketing New challenges to international marketing (pp. 277-319): Emerald Group Publishing Limited.

Imran, M., Aziz, A., \& Hamid, S. (2017). Total Quality Management, Export Market Orientation and Firm Export Performance: A Conceptual Framework. International Journal of Academic Research in Business and Social Sciences, 7(9), 591-601. doi:10.6007/IJARBSS/v7-i9/3382

Imran, M., Hamid, S., \& Aziz, A. (2018). The influence of TQM on export performance of SMEs: Empirical evidence from manufacturing sector in Pakistan using PLS-SEM. Management Science Letters, 8(5), 483-496.

Imran, M., Zhouquan, J., Haque, U. A., Urbanski, M., \& Nair, S. L. S. (2018). Determinants of Firm's Export Performance in China's Automobile industry. Sustainability, 10(11), 4078.

Kohli, A. K., Jaworski, B. J., \& Kumar, A. (1993). MARKOR: a measure of market orientation. Journal of 
Marketing research, 467-477.

Lages, L. F., Silva, G., \& Styles, C. (2009). Relationship capabilities, quality, and innovation as determinants of export performance. Journal of International Marketing, 17(4), 47-70.

LCCI. (2017). Untapped Export Potentail of Pakistan. Retrieved from Lahore, Pakistan: http://www.lcci.com.pk/research-department/lccirnd/attachments/export\%20book-final.pdf

Lee, H.-H., \& Lee, C.-Y. (2014). The effects of total quality management and organisational learning on business performance: evidence from Taiwanese insurance industries. Total Quality Management $\mathcal{E}$ Business Excellence, 25(9-10), 1072-1087.

Mac, L., \& Evangelista, F. (2016). The relative impact of market orientation and entrepreneurship on export performance: do we really know enough? Journal of Global Marketing, 29(5), 266-281.

Manzoor, S. (2016). Furniture industry in Pakistan and its export status. Retrieved from https://www.slideshare.net/jik 1959/1-furniture-industry-in-pakistan-research-apper

Mehra, S., Hoffman, J. M., \& Sirias, D. (2001). TQM as a management strategy for the next millennia. International Journal of Operations \& Production Management, 21(5/6), 855-876.

Morgan, N. A., Kaleka, A., \& Katsikeas, C. S. (2004). Antecedents of export venture performance: A theoretical model and empirical assessment. Journal of marketing, 68(1), 90-108.

Munizu, M. (2013). The Impact of total quality management practices towards competitive advantage and organizational performance: Case of fishery industry in South Sulawesi Province of Indonesia.

Nation, T. (2016). Ahsan stresses need for non-traditional SMEs promotion. The Nation. Retrieved from http://nation.com.pk/national/18-Oct-2016/ahsan-stresses-need-for-non-traditional-smespromotion

Nunnally, J. C., \& Bernstein, I. H. (1978). Psychometric theory.

Pascucci, F., Bartoloni, S., \& Gregori, G. L. (2016). Export market orientation and international performance in the context of SMEs. Journal of Small Business $\mathcal{E}$ Entrepreneurship, 1-15.

Petersen, P. B. (1999). Total quality management and the Deming approach to quality management. Journal of management History, 5(8), 468-488.

Presutti, M., Boari, C., \& Fratocchi, L. (2016). The evolution of inter-organisational social capital with foreign customers: Its direct and interactive effects on SMEs' foreign performance. Journal of World Business, 51(5), 760-773.

Presutti, M., Boari, C., Majocchi, A., \& Molina-Morales, X. (2017). Distance to Customers, Absorptive Capacity, and Innovation in High-Tech Firms: The Dark Face of Geographical Proximity. Journal of Small Business Management.

Presutti, M., \& Odorici, V. (2018). Linking entrepreneurial and market orientation to the SME's performance growth: the moderating role of entrepreneurial experience and networks. International Entrepreneurship and Management Journal, 1-24.

PSDF. (2015). Furniture Sector in Punjab: Sector Skill Study. Retrieved from House 25, Street 35, Sector G14/4, Islamabad, Pakistan: http://www.idspak.com

Radzi, M. S. N. M., Junoh, A. S., Hussain, N. S. N., Abd, Z., \& Aziz, N. F. M. Z. (2015). The effect of information, communication and technology (ICT) and quality management to export performance of Malaysian's SME in manufacturing sector.

Salkind, N. J. (2012). Exploring research: Pearson Education, Inc, New Jersey.

Samson, A., \& Mahmood, R. (2015). Fostering Export Performance in SMEs: The Roles of Export Market Orientation and Learning Orientation in Turbulent Environment. International Journal of Economic Perspectives, 9(2), 28.

Saraph, J. V., Benson, P. G., \& Schroeder, R. G. (1989). An instrument for measuring the critical factors of quality management. Decision sciences, 20(4), 810-829.

Sashkin, M. (1993). Putting total quality management to work: what TQM means, how to use it, \& how to sustain it over the long run (Vol. 2039): Berrett-Koehler Publishers. 
Saunders, M., \& Lewis, P. (2015). Research methods for business students (Vol. 7): Pearson Education Limited,

Schmitz, H., \& Knorringa, P. (2000). Learning from global buyers. Journal of development studies, 37(2), 177205.

Shafiq, M., Lasrado, F., \& Hafeez, K. (2017). The effect of TQM on organisational performance: empirical evidence from the textile sector of a developing country using SEM. Total Quality Management $\mathcal{E}$ Business Excellence, 1-22. doi:10.1080/14783363.2017.1283211

Shoham, A. (1998). Export performance: a conceptualization and empirical assessment. Journal of international marketing, 59-81.

Sidin, S. M. (2017). Impact of environmental factors as moderator on export marketing performance in wooden furniture industry. Jurnal Kemanusiaan, 6(1).

Singh, H., \& Mahmood, R. (2013). Determining the effect of export market orientation on export performance of small and medium enterprises in Malaysia: An exploratory study. Advances in Management and Applied Economics, 3(6), 223.

Singh, H., Saufi, R. A., \& Hassan, A. A. G. (2017). Export market orientation strategy, external environment, and export performance of SMEs in Malaysia. Prabandhan: Indian Journal of Management, 10(12), 32-49.

Suárez, E., Calvo-Mora, A., Roldán, J. L., \& Periáñez-Cristóbal, R. (2017). Quantitative research on the EFQM excellence model: A systematic literature review (1991-2015). European Research on Management and Business Economics, 23(3), 147-156.

Terziovski, M. (2003). The relationship between networking practices and business excellence: a study of small to medium enterprises (SMEs). Measuring business excellence, 7(2), 78-92.

Thornton, S. C., Henneberg, S. C., \& Naudé, P. (2013). Understanding types of organizational networking behaviors in the UK manufacturing sector. Industrial Marketing Management, 42(7), 1154-1166.

Thornton, S. C., Henneberg, S. C., \& Naudé, P. (2015). An empirical investigation of network-oriented behaviors in business-to-business markets. Industrial Marketing Management, 49, 167-180.

$\mathrm{Wu}, \mathrm{W} .-\mathrm{K} .$, \& Chiu, S. W. (2016). The impact of guanxi positioning on the quality of manufacturer-retailer channel relationships: Evidence from Taiwanese SMEs. Journal of Business Research, 69(9), 33983405.

Yusof, S. r. M., \& Aspinwall, E. (2000). Total quality management implementation frameworks: comparison and review. Total Quality Management, 11(3), 281-294. 